\title{
PENGGUNAAN ANALISIS STRUCTURAL EQUATION MODELLING (SEM) SECOND ORDER DALAM MENGIDENTIFIKASI PENGARUH KECERDASAN EMOSIONAL DAN INTELEKTUAL TERHADAP PRESTASI BELAJAR
}

\author{
Anik Anekawati \\ Dosen FKIP Universitas Wiraraja Sumenep \\ Email : luk.luk10@yahoo.co.id
}

\begin{abstract}
Abstrak
Kecerdasan emosional dan kecerdasan intelektual mempunyai peranan yang sangat penting dalam upaya peningkatan kualitas hasil belajar. Salah satu diantara mereka tidak boleh ada yang dimarginalkan. Tujuan penelitian ini adalah mengidentifikasi indikator-indikator apa saja yang dapat digunakan untuk mengukur kecerdasan emosional dan kecerdasan intelektual, serta bagaimana pengaruh kecerdasan emosional dan kecerdasan intelektual terhadap prestasi belajar. Teknik analisis statistika yang dipakai adalah Structural Equation Modelling Second Order. Pengukuran kecerdasan emosional menggunakan Confirmatory Factor Analysis (CFA) Second Order karena kecerdasan emosional mempunyai lima dimensi, dimana masing-masing dimensi memiliki beberapa indikator, sehingga dilakukan pengujian CFA dua kali. Data yang digunakan dalam penelitian ini merupakan data primer dan sekunder dengan jumlah sampel sebanyak 184. Karena asumsi normalitas multivariat tidak terpenuhi, maka dilakukan estimasi dengan menggunakan prosedur bootstrap. Hasil analisis menunjukkan bahwa model struktural yang dikembangkan berdasarkan teori dalam mengidentifikasi pengaruh kecerdasan emosional dan kecerdasan intelektual terhadap prestasi belajar adalah sesuai dengan studi kasus untuk siswa SMA/MA di Kabupaten Sumenep daratan (diluar di kepulauan). Dari kelima dimensi, hanya dimensi Memotivasi Diri Sendiri yang bisa digunakan untuk mengukur variabel Kecerdasan Emosioanal, sehingga variabel kecerdasan emosional tidak berpengaruh secara nyata terhadap prestasi belajar. Kecerdasan intelektual berpengaruh secara nyata terhadap prestasi belajar siswa sebesar 0,387.
\end{abstract}

Kata kunci : kecerdasan emosional, kecerdasan inteletual, structural equation modelling, second order.

\section{Pendahuluan}

Perkembangan penelitian pendidikan terdahulu telah menempatkan faktor intelegensi (intelektual) sebagai bagian paling penting dalam proses pembelajaran, sebab ia memegang aspek kognitif (Hudgins, 1987). Bahkan, intelegensi mendominasi para ahli untuk menarik kesimpulan tentang perbedaan kemampuan siswa (Santrock, 2010). Meski beberapa ahli menafsirkannya berbedabeda, namun intelegensi pada dasarnya adalah kemampuan global seseorang individu (Anastasi, 1997) dalam memecahkan masalah serta kemampuan beradaptasi dan belajar dari pengalaman hidup seharihari (Santrock, 2010).

Inteligensi lebih cenderung melihat kemampuan kognitif yang dimiliki organisme untuk menyesuaikan diri secara efektif pada lingkungan yang kompleks (Galton dalam Joseph, 1978). Dalam pandangan Teori Intelegensi Triarkis (Sternberg, 2000), intelegensi pada aspek kognitif merupakan bentuk dari intelegensi analitis, yaitu kemampuan dalam: (1) menganalisis, (2) menilai, (3) mengevaluasi, (4) membandingkan, dan (5) mempertentangkan. Pada sekolah umum (konvensional), umumnya siswa dengan kemampuan analitis tinggi cenderung lebih disukai (Santrock, 2010), sebab mereka dianggap gifted, pintar, lebih mudah menerima pelajaran, mendapat nilai tinggi, serta mudah masuk ke jenjang pendidikan lebih tinggi.

Kemampuan intelektual dapat diukur dengan cara mempelajari tindakan (demonstrasi) intelegensi individu yang bersangkutan saat itu (Hudgins, 1982) dalam hubungannya dengan norma usia yang ada (Eysenck, 1981). Dalam bahasa sesederhana, IQ adalah perbandingan antara usia mental (tingkat perkembangan mental individu yang berhubungan dengan perkembangan lainnya) seseorang saat (tes) itu dibagi dengan usia kronologis, dikalikan 100 (Santrock, 2010). Mengukur IQ dilakukan menggunakan suatu alat tes yang biasa disebut IQ (Intellegence Quotient). Seseorang dikatakan mememiki IQ berklasifikasi baik (atau sangat baik) manakala hasil tes menunjukkan usia mentalnya lebih tinggi dibandingkan dengan usia kronologisnya, dan sebaliknya maka individu tersebut berklasifikasi IQ rendah (atau sangat rendah). 
Terdapat beberapa alat tes IQ, namun yang paling banyak dipakai untuk menilai intelegensi siswa adalah Tes Stanford-Binet (Aiken dalam Santrock, 2010), meliputi kemampuan: (1) penalaran verbal, (2) penalaran kuantitatif, (3) penalaran visual abstrak, dan (4) memori jangka pendek. Menurut Wiramiharja (dalam Trihandini, 2005), indikator kecerdasan intelektual pada domain kognitif meliputi: (1) Kemampuan figur yaitu pemahaman dan nalar dalam bidang bentuk; (2) Kemampuan verbal yaitu pemahaman dan nalar dalam bidang bahasa; dan (3) Pemahaman dan nalar dalam bidang numerik atau berkaitan dengan angka biasa disebut dengan kemampuan numerik. Sedangkan, menurut Thurstone (dalam Gregory, 2000) bahwa intelegensi spesifik seseorang dapat diukur melalui: (1) pemahaman verbal, (2) kemampuan angka, (3) kefasihan kata, (4) visualisasi spasial, (5) memori asosiatif, (6) penalaran umum, dan (7) kecepatan persepsi (deduktif dan induktif).

Dalam kurun waktu terakhir, masalah intelegensi tersebut mendapat berbagai kritik, sebab siswa sebagai seorang individu dilahirkan dengan karakteristik tertentu beserta segala kelebihan dan kekurangannya (Santrock, 2010). Fakta kontradiktif, banyak siswa yang memiliki taraf intelegensi (IQ) tinggi, tetapi memiliki prestasi belajar rendah, gagal dalam pekerjaan, lemah dalam membangun hubungan atau gagal dalam kehidupan sosialnya. Sebaliknya, banyak siswa yang berprestasi rendah, sering dimarahi guru, dan disadvantage tetapi mereka menjadi pengusaha atau politikus sukses. Artinya, Kecerdasan intelektual bukan merupakan satu-satunya faktor yang menentukan keberhasilan prestasi belajar (hidup) siswa. Menurut Teori Intelegensi Triarkis (Sternberg, 2000), kecerdasan praktis dan kreatif serta pengalaman sangat menentukan dalam diri seseorang. Kecerdasan praktis dalam teori Gardner meliputi kemampuan intrapersonal dan interpersonal, yang oleh Salovey dan Goleman (Santrock, 2010) disebut intelegensi emosional atau Emotional Quotient(EQ). Bahkan, menurut Goleman (1995; 2000), kecerdasan intelektual (IQ) hanya menyumbang $20 \%$ pada kesuksesan seseorang, sedangkan $80 \%$ adalah sumbangan kecerdasan emosional.

Kecerdasan emosional (EQ) adalah kecerdasan sosial (Goleman, 2002), yang merujuk pada kemampuan untuk memonitor perasaan diri sendiri dan perasaan orang lain (Santrock, 2010), sehingga mendorong seorang individu untuk mampu merespon atau bertingkah laku (bertindak) terhadap stimulus dengan tepat (seimbang), baik yang berasal dari dalam maupun dari luar dirinya yang tidak dipengaruhi oleh faktor bawaan atau hereditas (Shapiro, 1998). EQ lebih memfokuskan pada kemampuan untuk menggunakan, mengaplikasi, serta mempraktikan (Santrock, 2010) sehingga Goleman menganggap IQ tidak lebih penting daripada EQ.

Terdapat empat wilayah EQ (Goleman, 2002; Santrock, 2010), yaitu kemampuan diri dalam: (1) mengenali emosi diri, yaitu suatu kemampuan untuk mengenali perasaan sewaktu perasaan itu terjadi atau metamood, (2) mengelola emosi, yaitu kemampuan mengontrol emosi dengan tepat atau seimbang, seperti: menghibur diri sendiri, melepaskan kecemasan, kemurungan atau ketersinggungan dan akibat-akibat yang ditimbulkannya, serta kemampuan untuk bangkit dari perasaan-perasaan yang menekan; (3) memotivasi diri sendiri, yaitu ketekunan untuk menahan diri terhadap kepuasan dan mengendalikan dorongan hati, serta mempunyai perasaan motivasi yang positif, seperti: antusiasme, gairah, optimis dan keyakinan diri; (4) mengenali emosi orang lain (empati), yaitu kemampuan untuk menangkap sinyal-sinyal sosial tersembunyi yang mengisyaratkan hal-hal yang dibutuhkan orang lain sehingga ia mampu menerima sudut pandang orang lain, peka terhadap perasaan dan lebih mampu untuk mendengarkan orang lain; dan (5) berempati serta kemampuan bekerja sama, berkomunikasi dan membina hubungan dengan orang lain (Salovey dalam Santrock, 2010). Bahkan, kunci utama orangorang yang hebat adalah mampu berkomunikasi dengan orang lain, sebab ia dapat menjadi teman yang menyenangkan karena kemampuannya berkomunikasi (Goleman, 2002).

Agar sukses dalam belajar atau dalam kehidupannya, siswa harus mengombinasikan kedua kecerdasan di atas (Santrock, 2010), sehingga selain tetap fokus pada "belajar dan mengingat" informasi sebagaimana tuntutan pembelajaran konvensional, mereka juga harus memiliki mental dan emosi yang baik, ambisi (motivasi) dan kreativitas yang lebih tinggi, serta berkepribadian menarik bagi orang lain (Hudgins, 1982; Santrock, 2010). Meski banyak kritik yang menganggap bahwa EQ berbeda dengan konsep intelegensi (Santrock, 2010), namun secara logika bahwa IQ siswa tidak dapat berfungsi dan berkembang baik jika tidak didukung partisipasi penghayatan dan pengelolaan emosi diri serta motivasi diri untuk berhasil terhadap mata pelajaran yang disampaikan guru. Keterpaduan antara IQ dan EQ siswa merupakan kunci keberhasilan belajar siswa di sekolah (Goleman, 2000).

Berdasarkan deskripsi di atas, diperlukan sebuah penelitian tentang pengaruh simultan kecerdasan emosi dan kecerdasan intelektual terhadap prestasi belajar. Penggunaan Structural 
Equation Modelling (SEM) sebagai alat untuk menganalisis, didasarkan pada keunggulan SEM sebagai alat analisis statistik yang paling sesuai untuk menjelaskan fenomena-fenomena sosial pada umumnya dan mampu menjelaskan konstribusi masing-masing indikator dalam membentuk konstrak laten.

\section{Structural Equation Modeling (SEM)}

Structural Equation Modeling (SEM) adalah teknik analisis statistika yang mengkombinasikan beberapa aspek yang terdapat pada path analysis dan Confirmatori Faktor Analysis (CFA) untuk mengestimasi beberapa persamaan secara simultan. Model persamaan struktural pada SEM merupakan generasi kedua teknik analisis multivariat yang memungkinkan peneliti untuk menguji hubungan antara variabel yang kompleks untuk memperoleh gambaran menyeluruh mengenai keseluruhan model (Ferdinand, 2000). Secara umum, model SEM dapat dibagi menjadi dua bagian utama, yaitu model pengukuran (measurement model) dan model struktural (structural model).

Measurement model adalah bagian dari model SEM, yang menggambarkan hubungan antara variabel laten dengan indikator-indikatornya. Pemodelan ini bertujuan untuk mengukur dimensidimensi yang membentuk sebuah faktor yang dievaluasi dengan menggunakan teknik analisis faktor konfirmatori atau Confirmatori Faktor Analysis/CFA (Kline, 2005). Tingkat kevalidan setiap indikator dalam mengukur variabel laten ditunjukkan oleh nilai loading $(\lambda)$. Indikator dikatakan valid pada saat mampu mengukur konstruk jika nilai loading $\lambda \geq 0.7$ (Ghozali,2004).

Model Struktural (structural model) adalah hubungan antara variabel laten (konstruk) independen dan dependen. Dalam Model Struktural, variabel laten dibedakan menjadi dua macam, yakni variabel laten eksogen dan variabel laten endogen. Variabel laten eksogen adalah variabel laten yang tidak dipengaruhi oleh variabel laten yang lainnya dalam model. Sedangkan variabel laten endogen adalah variabel laten yang dipengaruhi atau mempengaruhi oleh variabel laten lainnya dalam suatu model penelitian. Pola hubungan antar variabel laten dalam model struktural ini dianalisis dengan pendekatan Path Analysis yang identik dengan Analisis Regresi. Pada model struktural dapat diketahui besar pengaruh variabel eksogen terhadap variabel endogen baik secara langsung maupun tidak langsung.

Model umum persamaan struktural dapat dituliskan dalam persamaan matrik sebagai berikut (Johnson, 1992)

$$
\eta_{(m x 1)}=B_{(m x m)} \eta_{m x 1}+\Gamma_{(m x n)} \xi_{(n x 1)}+\zeta_{(m x 1)}
$$

Dimana :

$\eta=$ Variabel laten endogen

$B=$ Koefisien pengaruh variabel laten endogen

$\Gamma=$ Koefisien pengaruh variabel laten eksogen

$\xi=$ Variabel laten eksogen

$\zeta=$ Error model

$m=$ Banyaknya variabel laten endogen

$n=$ Banyaknya variabel laten eksogen

Keandalan variabel laten dapat diketahui dari nilai construct reliability $\left(\rho_{c}\right)$ dengan rumus sebagai berikut

dimana :

$$
\rho_{c}=\frac{\left(\sum_{i=1}^{p} \lambda_{i}\right)^{2}}{\left[\left(\sum_{i=1}^{p} \lambda_{i}\right)^{2}+\left(\sum_{i=1}^{p} \delta_{i}\right)\right]}
$$

$$
\begin{aligned}
& \rho_{c}=\text { construct reliability } \\
& \lambda=\text { loading Faktor } \text { variabel indikator } \\
& \delta=\text { error variance } \text { variabel indikator } \\
& \mathrm{p}=\text { banyaknya indikator variabel laten }
\end{aligned}
$$


Variabel laten dikatakan andal jika nilai constructreliability $\left(\rho_{c}\right)$ lebih dari 0,6 (Ghozali \& Fuad, 2005). Asumsi-asumsi yang harus dipenuhi dalam model structural adalah: noemalitas dan multikolinieritas.

Secara umum identifikasi model memfokuskan pada pertanyaan apakah ada atau tidak unique set parameter konsisten terhadap data. Jika ada solusi unik dari nilai parameter struktural, maka model dikatakan teridentifikasi. Sebagai konsekuensinya parameter dapat diestimasi dan model dengan sendirinya dapat diuji (testable) (Ghozali \& Fuad, 2005). Sebaliknya, jika model tidak dapat diidentifikasi, hal ini berarti parameter adalah sembarang (arbriter) yang bermakna nilai parameter yang berbeda dapat mendapatkan model yang sama.

Tujuan dari menguji kesesuaian model yaitu : 1) mengevaluasi apakah model pengukuran yang diusulkan fit atau tidak terhadap data; 2) mengevaluasi apakah model pengukuran yang diusulkan bersifat unidimensional atau tidak. Pada penelitian ini pengujian dilakukan dengan menggunakan beberapa ukuran kesesuaian model sebagaimana tertera pada Tabel 2.1.

Tabel 2.1 Goodness of fit Statistics Indeces

\begin{tabular}{ll}
\hline Goodness of fit Index & Nilai yang diharapkan \\
\hline$\chi^{2}-$ Chi Square & Diharapkan kecil \\
$P$-value & $\geq 0,05$ \\
RMSEA & $\leq 0,08$ \\
GFI & $\geq 0,9$ \\
AGFI & $\geq 0,9$ \\
CFI & $\geq 0,9$ \\
\hline
\end{tabular}

Sumber : Ghozali dan Fuad, 2005

Mengacu pada permasalahan di atas, maka tujuan yang ingin dicapai dalam penelitian ini adalah: (1) mengidentifikasi variabel indikator yang dapat mengukur variabel kecerdasan intelektual dan kecerdasan emosional; dan (2) mengetahui pengaruh variabel kecerdasan intelektual dan kecerdasan emosional terhadap prestasi belajar.

\section{Metode Penelitian}

Populasi dalam penelitian ini adalah seluruh siswa kelas II SMA/MA di Kabupaten Sumenep. Teknik sampling yang digunakan adalah Metode Sampling Cluster, dengan jumlah sampel penelitian 184 siswa. Rincian jenis data, variabel, dan indikator yang digunakan dalam penelitian dapat dilihat pada Tabel 3.1.

Tabel 3.1 Jenis Variabel, Indikator dan Jenis Data

\begin{tabular}{|l|l|l|l|l|}
\hline \multicolumn{1}{|c|}{ Variabel } & Indikator Second Order & Indikator First Order & Jenis Data & \multicolumn{1}{|c|}{ Instrumen } \\
\hline $\begin{array}{l}\text { Prestasi } \\
\text { Belajar } \\
\text { (endogen) }\end{array}$ & & Nilai rata-rata rapor \\
kelas 10 & Sekunder & Rapor \\
\hline \multirow{4}{*}{$\begin{array}{l}\text { Kecerdasan } \\
\text { Emosional } \\
\text { (eksogen) }\end{array}$} & Mengenali emosi diri (MED) & MED1-MED6 & Primer & Angket \\
\cline { 2 - 5 } & Mengelola emosi (ME) & ME1-ME6 & Primer & Angket \\
\cline { 2 - 5 } & Memotivasi diri sendiri (MD) & MD1-MD8 & Primer & Angket \\
\cline { 2 - 5 } & $\begin{array}{l}\text { Mengenali emosi orang } \\
\text { lain(MEO) }\end{array}$ & MEO1-MEO5 & Primer & Angket \\
\cline { 2 - 5 } & Membina hubungan (MH) & MH1-MH5 & Primer & Angket \\
\cline { 2 - 5 } & - & Penalaran Deduktif & Primer & Tes Penalaran \\
\cline { 2 - 5 } & - & Penalaran Induktif & Primer & Tes Penalaran \\
\cline { 2 - 5 } $\begin{array}{l}\text { Kecerdasan } \\
\text { Intelektual } \\
\text { (eksogen) }\end{array}$ & - & Pemahaman & Sekunder & Tes Aptitute \\
\cline { 2 - 5 } & - & Daya Ingat & Sekunder & Tes Aptitute \\
\cline { 2 - 5 } & - & Kemampuan Verbal & Sekunder & Tes Aptitute \\
\cline { 2 - 5 } & - & Kemampuan Numerik & Sekunder & Tes Aptitute \\
\cline { 2 - 5 } & - & Daya Abstrak & Sekunder & Tes Aptitute \\
\cline { 2 - 5 } & - & Penalaran Umum & Sekunder & Tes Aptitute \\
\hline
\end{tabular}


Tahap analisis yang dilakukan dalam penelitian ini didasarkan pada tujuan dari penelitian, yang meliputi:

1. Pengujian multinormalitas dan multikolinearitas.

2. Pengujian unidimensionalitas setiap variabel laten dengan menggunakan Confirmatory Faktor Analysis (CFA).

3. Analisis model persamaan structural, dengan langkah-langkah sebagai berikut :

a. Pengembangan model berbasis konsep dan teori

Pada tahap ini adalah membangun sebuah model penelitian, dimana prestasi belajar dipengaruhi oleh kecerdasan emosional dan kecerdasan intelektual. Kecerdasan emosional dengan subvariabel sebagai order secondnya meliputi: (1) kemampuan mengenali emosi diri (MED), (2) kemampuan mengelola emosi (ME), (3) kemampuan memotivasi diri sendiri (MD), (4) kemampuan mengenali emosi orang lain (MEO) dan (5) kemampuan membina hubungan dengan orang lain (MU). Kecerdasan intelektual diukur melalui indikator antara lain: (1) kemampuan penalaran umum, (2) penalaran deduktif, (3) penalaran induktif, (4) pemahaman, (5) daya ingat, (6) kemampuan verbal, (7) kemampuan numerik, dan (8) daya abstrak.

b. Mengkonstruksi diagram Path

Model teori yang dibentuk dalam studi literatur dikembangakan dalam sebuah diagram jalur. Diagram jalur yang menunjukkan hubungan kausal antar variabel laten dan variabel manifes ditunjukan pada Gambar 3.1.

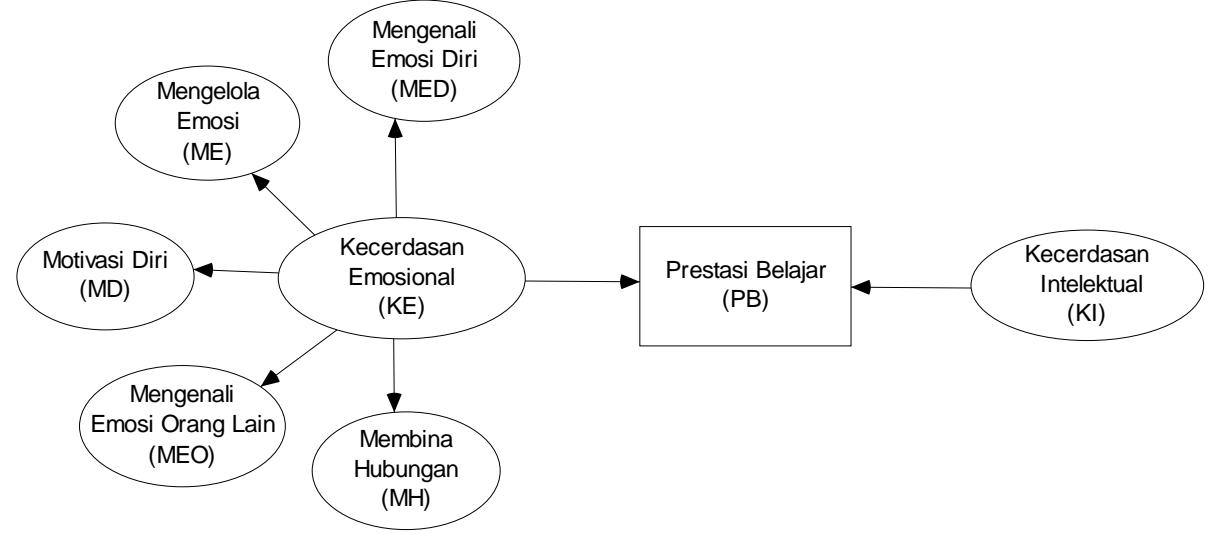

Gambar 3.1 Diagram Jalur Model

c. Konversi Diagram Jalur Kedalam Persamaan

Diagram Jalur pada Gambar 3.1 di atas dapat dikonversikan menjadi model struktural sebagaimana pada persamaan berikut : $\mathrm{PB}=\gamma_{1} \mathrm{KE}+\gamma_{2} \mathrm{KI}+\zeta_{1}$

d. Memilih matriks input

Dalam penelitian ini, tujuan yang ingin diperoleh ialah melihat variabel laten apa saja yang paling berpengaruh terhadap prestasi belajar dengan model struktural yang memiliki justifikasi teori sebelumnya dan dilakukan interpretasi terhadap besar kecilnya pengaruh kausalitas pada jalur-jalur yang ada pada model, maka input data yang digunakan adalah input matrik varian kovarian.

e. $\quad$ Evaluasi Goodness of fit

Goodness of fit yang dihasilkan dari perhitungan Model Persamaan Struktural harus memenuhi kriteria goodness of fit yang dapat dilihat pada tabel 2.1

f. Interpretasi dan modifikasi model.

Interpretasi model meliputi menyelidiki signifikansi pengaruh variabel laten eksogen terhadap variabel laten endogen. 


\section{Hasil Dan Pembahasan}

Karakteristik responden dapat diketahui melalui analisis deskriptif berdasarkan data yang diperoleh. Hasil deskriptif karakteristik responden penelitian dapat dilihat pada Tabel 4.1.

Tabel 4.1 Karakteristik Responden

\begin{tabular}{|c|l|c|c|c|}
\hline No & Nama Sekolah & Laki-laki & Wanita & Jumlah \\
\hline 1 & MAN Sumenep & 36 & 44 & 80 \\
\hline $\mathbf{2}$ & SMAN 1 Bluto & 23 & 50 & 73 \\
\hline $\mathbf{3}$ & MA Al-Amien Putri & 0 & 31 & 31 \\
\hline \multicolumn{2}{|c|}{ Total } & 59 & 125 & 184 \\
\hline
\end{tabular}

\section{Uji Multinormalitas}

Hasil pengujian multinormalitas dapat dilihat pada output assessment of normality. Hasil uji normalitas data memberikan nilai critical ratio multivariate sebesar 14,251 dan dibandingkan dengan nilai kritisnya 1,96 (signifikansi pada 5\%), maka dapat disimpulkan bahwa data tidak berdistribusi normal. Selanjutnya dilakukan estimasi dengan menggunakan prosedur bootstrap. Pada penelitian ini dilakukan multiple sub-sample dengan ukuran 500 yang diambil dari sampel asli secara random dengan replacement.

\section{Uji Multikolinieritas}

Hasil perhitungan melalui software didapatkan nilai $\mathrm{p}$ value pada determinan of sample covarians matrix 0,250. Nilai ini lebih besar dari 0,05 sehingga dapat disimpulkan bahwa tidak terdapat masalah kolinieritas dan singularitas pada data yang dianalisis

\section{Confirmatory Factor Analysis (CFA) First Order}

Pengujian ini bertujuan untuk menguji validitas, reliabilitas serta kontribusi yang diberikan indikator dalam mengukur variabel laten pada order pertama. Untuk itu perlu dilihat nilai convergent validity dari indikator-indikator pembentuk konstruk laten, yaitu nilai signifikansi dari factor loading dan standardized loading factor.

\section{Confirmatory Factor Analysis (CFA) Variabel Mengenali Emosi Diri}

Tabel 4.2 Nilai Faktor Loading Variabel Mengenali Emosi Diri

\begin{tabular}{lcccccc}
\hline \multicolumn{2}{c}{ Hubungan } & Faktor Loading & $\boldsymbol{T}$ & P-value & Keterangan \\
\hline MED6 & $<---$ & MED & 0,174 & & & Tidak Signifikan \\
MED5 & $<---$ & MED & 0,190 & 1,601 & 0,109 & Tidak Signifikan \\
MED4 & $<---$ & MED & 0,250 & 1,787 & 0,074 & Tidak Signifikan \\
MED3 & $<---$ & MED & 0,279 & 1,851 & 0,064 & Tidak Signifikan \\
MED2 & $<---$ & MED & 0,268 & 1,828 & 0,068 & Tidak Signifikan \\
MED1 & $<---$ & MED & 0,287 & 1,865 & 0,062 & Tidak Signifikan
\end{tabular}

Sumber: Hasil Olahan Peneliti

Dengan melihat nilai $P$-value pada Tabel 4.2 diketahui bahwa secara statistik enam indikator tidak signifikan secara statistika karena nilai $\mathrm{p}_{\text {value }}$ lebih besar dari $\alpha(5 \%)$ dan nilai faktor loading kurang dari 0,5. Dengan demikian semua indikator tidak dapat digunakan untuk mengukur variabel laten Mengenali Emosi Diri. 


\section{Confirmatory Factor Analysis (CFA) Variabel Mengelola Emosi}

Tabel 4.3. Nilai Faktor Loading Variabel Mengelola Emosi

\begin{tabular}{lllrlcc}
\hline \multicolumn{2}{c}{ Hubungan } & Faktor Loading & T & P-value & Keterangan \\
\hline ME6 & $<--$ & ME & 0,261 & & & Signifikan \\
ME5 & $<---$ & ME & 0,331 & 2,344 & 0,019 & Signifikan \\
ME4 & $<--$ & ME & 0,307 & 2,271 & 0,023 & Signifikan \\
ME3 & $<--$ & ME & 0,389 & 2,483 & 0,013 & Signifikan \\
ME2 & $<---$ & ME & 0,258 & 2,086 & 0,037 & Signifikan \\
ME1 & $<---$ & ME & 0,198 & 1,784 & 0,074 & Tidak Signifikan
\end{tabular}

Sumber: Hasil Olahan Peneliti

Dengan melihat nilai $P$-value pada Tabel 4.3 diketahui bahwa secara statistik lima variabel indikator signifikan secara statistika karena nilai $\mathrm{p}_{\text {value }}$ kurang dari $\alpha(5 \%)$, akan tetapi keenam indikator mempunyai nilai faktor loading kurang dari 0,5. Dengan demikian semua indikator tidak dapat digunakan untuk mengukur variabel laten Mengelola Emosi.

\section{Confirmatory Factor Analysis (CFA) Variabel Memotivasi Diri Sendiri}

Tabel 4.4. Nilai Faktor Loading Variabel Memotivasi Diri Sendiri

\begin{tabular}{lllrrrr}
\hline \multicolumn{2}{c}{ Hubungan } & Faktor Loading & \multicolumn{1}{c}{$\boldsymbol{T}$} & \multicolumn{1}{c}{$\boldsymbol{P}$-value } & Keterangan \\
\hline MDS8 & $<---$ & MD & 0,563 & 4,704 & $* * *$ & Signifikan \\
MDS7 & --- & MD & 0,514 & 4,486 & $* * *$ & Signifikan \\
MDS6 & --- & MD & 0,476 & 4,704 & $* * *$ & Signifikan \\
MDS5 & $<---$ & MD & 0,478 & 4,303 & $* * *$ & Signifikan \\
MDS4 & $<---$ & MD & 0,288 & 3,009 & 0,003 & Signifikan \\
MDS3 & $<---$ & MD & 0,431 & 4,037 & $* * *$ & Signifikan \\
MDS2 & $<$ & MD & 0,237 & 2,556 & 0,011 & Signifikan \\
MDS1 & $<$ & MD & 0,188 & 2,079 & 0,038 & Signifikan
\end{tabular}

Sumber: Hasil Olahan Peneliti

Dengan melihat nilai $P$-value pada Tabel 4.3 diketahui bahwa secara statistik delapan variabel indikator signifikan secara statistika karena nilai $\mathrm{p}_{\text {value }}$ kurang dari $\alpha(5 \%)$. Nilai faktor loading yang lebih dari 0,5 adalah MDS7 dan MDS8. Dengan demikian hanya 2 indikator dapat digunakan untuk mengukur variabel laten Memotivasi Diri Sendiri.

\section{Confirmatory Factor Analysis (CFA) Variabel Mengenali Emosi Orang Lain}

Tabel 4.5 Nilai Faktor Loading Variabel Mengenali Emosi Orang Lain

\begin{tabular}{lllllcc}
\hline \multicolumn{2}{c}{ Hubungan } & Faktor Loading & T & P-value & Keterangan \\
\hline MEO5 & $<---$ & MEO & 0,302 & & & Signifikan \\
MEO4 & --- & MEO & 0,474 & 2,968 & 0,003 & Signifikan \\
MEO3 & --- & MEO & 0,526 & 3,054 & 0,002 & Signifikan \\
MEO2 & --- & MEO & 0,434 & 2,885 & 0,004 & Signifikan \\
MEO1 & $<--$ & MEO & 0,254 & 2,230 & 0,026 & Signifikan
\end{tabular}

Sumber: Hasil Olahan Peneliti

Dengan melihat nilai $P$-value pada Tabel 4.5 diketahui bahwa secara statistik lima variabel indikator signifikan secara statistika karena nilai $\mathrm{p}_{\text {value }}$ kurang dari $\alpha(5 \%)$ dan hanya satu indikator 
yang nilai faktor loadingnya lebih dari 0,5 yaitu MEO3. Dengan demikian hanya 1 indikator yang dapat digunakan untuk mengukur variabel laten Mengenali Emosi Orang Lain.

\section{Confirmatory Factor Analysis (CFA) Variabel Membina Hubungan}

Tabel 4.6. Nilai Faktor Loading Variabel Membina Hubungan

\begin{tabular}{lccrrrr}
\hline \multicolumn{2}{c}{ Hubungan } & Faktor Loading & T & P-value & Keterangan \\
\hline MH1 & $<---$ & MH & 0,513 & & & Signifikan \\
MH2 & --- & MH & 0,408 & 4,149 & $* * *$ & Signifikan \\
MH3 & $<---$ & MH & 0,526 & 3,978 & $* * *$ & Signifikan \\
MH4 & $<---$ & MH & 0,255 & 2,830 & 0,005 & Signifikan \\
MH5 & $<---$ & MH & 0,206 & 2,330 & 0,020 & Signifikan
\end{tabular}

Sumber: Hasil Olahan Peneliti

Dengan melihat nilai $P$-value pada Tabel 4.6 diketahui bahwa secara statistik lima variabel indikator signifikan secara statistika karena nilai $\mathrm{p}_{\text {value }}$ kurang dari $\alpha(5 \%)$ dan hanya 2 indikator yang nilai faktor loadingnya lebih dari 0,5 yaitu MH1 dan MH3. Dengan demikian terdapat 2 indikator dapat digunakan untuk mengukur variabel laten Membina Hubungan.

\section{Confirmatory Factor Analysis (CFA) Variabel Kecerdasan Intelektual}

Tabel 4.7. Nilai Faktor Loading Variabel Kecerdasan Intelektual

\begin{tabular}{lcccccc}
\hline & \multicolumn{2}{c}{ Hubungan } & $\begin{array}{c}\text { Faktor } \\
\text { Loading }\end{array}$ & $\boldsymbol{T}$ & P-value & Keterangan \\
\hline Deduktif & $<---$ & Kecerdasan_Intelektual & 0,228 & & & Signifikan \\
Induktif & $<---$ & Kecerdasan_Intelektual & 0,295 & 2,328 &, 020 & Signifikan \\
Pmahaman & $<---$ & Kecerdasan_Intelektual & 0,649 & 2,814 &, 005 & Signifikan \\
DIngat & $<---$ & Kecerdasan_Intelektual & 0,614 & 2,795 &, 005 & Signifikan \\
KVerbal & $<---$ & Kecerdasan_Intelektual & 0,781 & 2,866 &, 004 & Signifikan \\
KNumerik & $<---$ & Kecerdasan_Intelektual & 0,765 & 2,861 &, 004 & Signifikan \\
DAbstrak & $<---$ & Kecerdasan_Intelektual & 0,568 & 2,764 &, 006 & Signifikan \\
Pnalaran & $<---$ & Kecerdasan_Intelektual & 0,663 & 2,821 &, 005 & Signifikan
\end{tabular}

Sumber: Hasil Olahan Peneliti

Dengan melihat nilai $P$-value pada Tabel 4.7 diketahui bahwa secara statistik delapan variabel

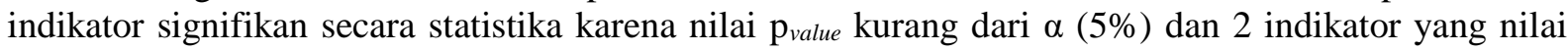
faktor loadingnya yang kurang dari 0,5, yaitu kemampuan penalaran induktif dan penalaran deduktif. Dengan demikian ada 6 indikator yang dapat digunakan untuk mengukur variabel laten Kecerdasan Intelektual.

\section{Confirmatory Factor Analysis (CFA) Second Order}

Pengujian ini bertujuan untuk menguji validitas, reliabilitas serta kontribusi yang diberikan indikator dalam mengukur variabel laten pada order kedua. 
Tabel 4.8 Nilai Faktor Loading Variabel Kecerdasan Emosional

\begin{tabular}{lccrrrc}
\hline & & Hubungan & Faktor Loading & \multicolumn{1}{c}{$\boldsymbol{T}$} & $\boldsymbol{P}$-value & Keterangan \\
\hline MED & $<---$ & Kecerdasan_Emosional & 1,052 & 2,059 & 0,040 & Signifikan \\
ME & $<---$ & Kecerdasan_Emosional & 0,902 & 2,669 & 0,008 & Signifikan \\
MD & $<---$ & Kecerdasan_Emosional & 0,838 & 4,207 & $* * *$ & Signifikan \\
MEO & $<---$ & Kecerdasan_Emosional & 0,846 & 2,987 & 0,003 & Signifikan \\
MH & $<---$ & Kecerdasan_Emosional & 1,007 & & & Signifikan
\end{tabular}

Sumber: Hasil Olahan Peneliti

Dengan melihat nilai $P$-value pada Tabel 4.8 diketahui bahwa secara statistik lima variabel indikator signifikan secara statistika karena nilai $\mathrm{p}_{\text {value }}$ kurang dari $\alpha(5 \%)$ dan nilai faktor loading lebih dari 0,5. Dengan demikian 5 indikator yang berupa varaibel laten dapat digunakan untuk mengukur variabel laten Kecerdasan Emosional.

\section{Uji Reliabilitas}

Setelah menguji variabel laten dengan CFA baik first order maupun second order untuk masing-masing variabel laten, tahap berikunya adalah menguji reliabilitas. Pengujian reliabilitas dilakukan dengan menggunakan pendekatan reliabilitas konstruk (construct reliability). Variabel laten dikatakan reliabel jika nilai reliabilitas konstruk lebih besar dari 0,60. Adapun untuk menghitung construct reliability adalah sebagai berikut :

$$
C R=\frac{\left[\sum_{i=1}^{n} \lambda_{i}\right]^{2}}{\left[\sum_{i=1}^{n} \lambda_{i}\right]^{2}+\left[\sum_{i=1}^{n} \delta_{i}\right]}
$$

Hasil perhitungan nilai CR dari masing-masing variabel laten dapat disajikan pada Tabel 4.9 berikut.

Tabel 4.9 Nilai CR Variabel Laten

\begin{tabular}{lc}
\hline \multicolumn{1}{c}{ Variabel Laten First Order } & CR \\
\hline MED & 0,271 \\
ME & 0,357 \\
MD & 0,604 \\
MEO & 0,488 \\
MH & 0,465 \\
Kecerdasan Intelektual & 0,803 \\
\hline \multicolumn{2}{c}{ Variabel Laten Second Order } \\
\hline Kecerdasan Emosional & CR \\
\hline
\end{tabular}

Berdasarkan nilai CR pada tabel 11 di atas maka dapat disimpulkan bahwa terdapat tiga variabel laten yang reliabel, yaitu Memotivasi Diri Sendiri (MD), Kecerdaan Intelektual (KI) dan Kecerdasan Emosional (KE) karena nilainya lebih dari 0,60.

\section{Model Persamaan Struktural}

Setelah dilakukan pengujian unidimensionalitas pada masing-masing variabel laten dengan menggunakan Confirmatory Faktor Analysis (CFA), maka tahap selanjutnya adalah melakukan analisis Model Persamaan Struktural dan secara grafis model struktural penuh seperti Gambar 4.1 


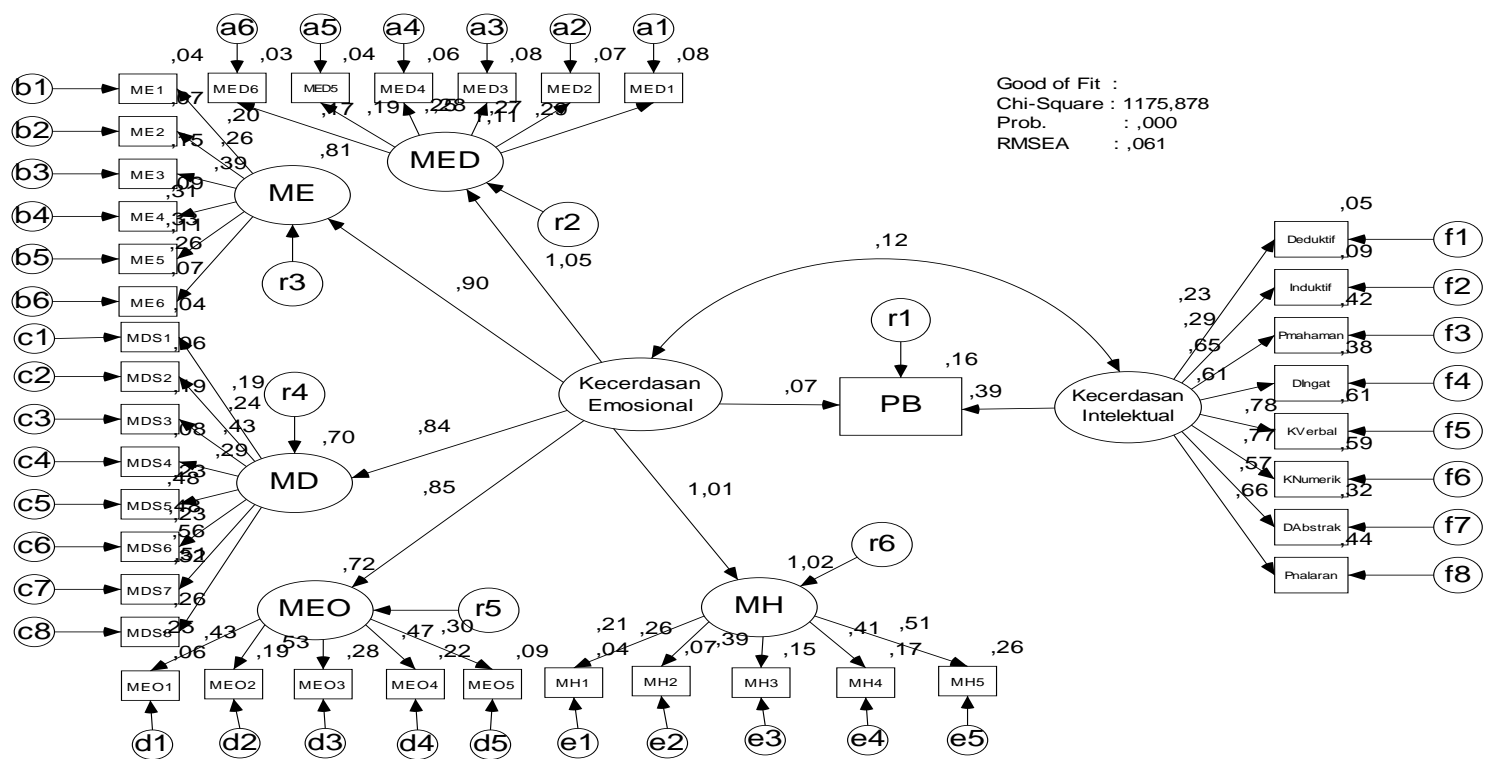

Gambar 2. Model Struktural Penuh

Berdasarkan diagram jalur di atas maka persamaan strukturalnya adalah :

$$
\mathrm{PB}=\gamma_{1} \mathrm{KE}+\gamma_{2} \mathrm{KI}+\zeta_{1}
$$

\section{Pengujian Model Struktural}

Berdasarkan hasil uji kelayakan model diperoleh nilai $p$-value kurang dari 0.05 dan nilai ChiSquare yang cukup besar. Ghozali (2011), nilai Chi-Square sensitif terhadap jumlah sampel, oleh karena itu perlu melihat nilai goodness of fit yang lainnya. Penelitian ini menggunakan goodness of fit RMSEA, dimana nilainya kurang dari 0,08 . Hal ini menunjukkan bahwa tidak terdapat perbedaan antara matriks varian kovarian populasi dengan matriks varian kovarian sampel. Sehingga model yang dikembangkan berdasarkan teori sesuai dengan kondisi SMA/MA di Sumenep.

Tabel 4.10 Estimasi Parameter Model Struktural

\begin{tabular}{lllrrc}
\hline & \multicolumn{1}{c}{ Hubungan } & Koeff Path & P-value & Keputusan \\
\hline PB & $<---$ & Kecerdasan_Emosional & 0,067 & 0,406 & Tidak Signifikan \\
PB & $<---$ & Kecerdasan_Intelektual & 0,387 & 0,011 & Signifikan
\end{tabular}

Berdasarkan Tabel 4.10 maka dapat diperoleh model struktural sebagai berikut:

$$
\mathrm{PB}=0,067 \mathrm{KE}+0,387 \mathrm{KI}
$$

Hasil estimasi pada Tabel 12 dapat diintepretasikan pada masing-masing koefisien jalur. Hubungan kausal antara variabel laten kecerdasan emosional terhadap prestasi belajar tidak signifikan dengan nilai pvalue 0,406 dimana nilai ini lebih besar dari $\alpha$. Oleh karena itu nilai koefisien jalur untuk variabel kecerdasan emosional yaitu 0.067 tidak bisa digunakan untuk memprediksikan hubungan kausal antara kecerdasan emosional dan prestasi belajar.

Hubungan kausal antara variabel laten kecerdasan intelektual terhadap prestasi belajar signifikan dengan nilai pvalue 0,011 dimana nilai ini kurang dari $\alpha$. Nilai koefisien jalur untuk variabel kecerdasan intelektual 0,387. Artinya semakin rendah kecerdasan intelektual maka prestasi belajar akan turun sebesar 0,387. 


\section{Analisis Pengaruh Antar Variabel Laten}

Pengaruh total merupakan penjumlahan antara pengaruh langsung dan pengaruh tidak langsung. Pada penelitian ini tidak ada pengaruh tidak langsung, sehingga total pengaruh merupakan pengaruh langsung. Tabel 4.11 menyajikan pengaruh langsung variabel eksogen terhadap endogen.

Tabel 4.11 Pengaruh Total Antar Variabel

\begin{tabular}{|l|c|}
\hline \multicolumn{1}{|c|}{ Variabel Endogen } & Variabel EksogenPrestasi Belajar \\
\hline Kecerdasan Emosional & 0,067 \\
\hline Kecerdasan Intelektual & 0,387 \\
\hline
\end{tabular}

\section{Sumber: Hasil Olahan Peneliti}

Dari tabel 4.11 dapat dijelaskan pengaruh variabel eksogen kecerdasan emosional sebesar 0,067 dan kecerdasan intelektual 0,387 terhadap variabel endogen prestasi belajar.

Pada penelitian ini terdapat 2 variabel eksogen, yaitu kecerdasan emosional dan kecerdasan intelektual serta 1 satu variabel endogen yaitu prestasi belajar. Kecerdasan emosional dijelaskan oleh lima first order faktor yaitu: (a) mengenali emosi diri; (b) mengelola emosi; (c) memotivasi diri sendiri; (d) mengenali emosi orang lain dan (e) membina hubungan. Dari hasil analisis, indikatorindikator yang dituangkan dalam pertanyaan dalam angket untuk menjelaskan faktor Mengenali Emosi Diri dan Mengelola Emosi tidak ada satupun yang valid dan reliabel. Artinya indikator yang dibuat tidak bisa digunakan untuk mengukur faktor tersebut. Faktor Memotivasi Diri Sendiri hanya dapat dijelaskan oleh indikator MDS 7 dan MDS8. Pertanyaan MDS 7 dan MDS8 terkait dengan dorongan berprestasi. Faktor Mengenali Emosi Orang Lain hanya dijelaskan oleh indikator MEO3. MOE3 terkait pertanyaan keinginan mendengarkan masalah orang lain. Faktor Membina Hubungan dapat dijelaskan oleh MH1 dan MH3. Kedua indikator tesebut terkait dengan pertanyaan kemapuan untuk bekerja sama.

Kelima faktor pembentuk variabel kecerdasan emosional di atas valid atau mampu digunakan untuk mengukur variabel kecerdasan emosional, akan tetapi hanya faktor memotivasi diri sendiri yang realibel atau konsisten. Sehingga hanya faktor memotivasi diri sendiri yang valid dan reliabel untuk menjelaskan kecerdasan emosional. Hasil ini menguatkan pandangan beberapa ahli yang menyatakan bahwa kecerdasan emosional tidak dapat dimasukkan ke dalam konsep intelegensi (Gardner 1998 dalam Santrock, 2010), meski pemahaman emosi adalah aspek penting kompetensi dan aktivitas fungsi manusia (Santrock, 2010).

Mengenali emosi diri, mengelola emosi diri dan orang lain, serta kemampuan membina hubungan berbeda wilayah dengan konsep intelegensi. Namun, motivasi memberikan sumbangan kuat terhadap aspek kognitif (Intelegensi). Motivasi adalah dorongan individu melakukan sesuatu (Hudgins, 1982), merupakan adalah energi membimbing individu (Seifert dan Sutton, 2009) untuk mencapai tujuan. Siswa yang memiliki motivasi tinggi akan menunjukkan kinerja belajar yang positif, sehingga mereka akan lebih terdorong untuk: (1) merubah perilaku, (2) mencapai tujuan, (3) lebih berminat belajar (4) menunjukkan kesuksesan, (5) menunjukkan kepercayaan, and (6) merubah nasib (Seifert dan Sutton, 2009). Bahkan, menurut Slameto (1995) bahwa seringkali anak didik yang tergolong cerdas tampak bodoh karena tidak memiliki motivasi untuk mencapai prestasi belajar. IQ hanya menyumbang seperempat dari kesuksesan belajar, dan sisanya adalah karena motivasi dan pengalaman pendidikan sebelumnya (Santrock, 2010).

Indikator yang mampu menjelaskan kecerdasan intelektual adalah: (1) pemahaman, (2) daya Ingat, (3) kemampuan verbal, (4) kemampuan numerik, (5) daya abstrak, dan (6) penalaran umum. Dari keenam faktor tersebut, faktor kemampuan verbal yang paling memberikan konstribusi terbesar untuk menjelaskan variabel kecerdasan intelektual, disusul faktor kemampuan numerik, sedangkan yang paling kecil adalah kemampuan daya abstrak. Karakter sampel yang didominasi siswa wanita $68 \%$ diduga mengontribusi fenomena tersebut. Anak perempuan lebih memiliki kemampuan dalam membaca dan menulis (kemampuan verbal) dibandingkan anak pria (Santrock, 2010). Kemampuan verbal tersebut memainkan peranan kuat dalam membentuk pemikiran. Beberapa penelitian menunjukkan bahwa anak laki-laki cenderung lebih buruk prestasi akademiknya di sekolah (Santrock, 2010). Hal ini disebabkan siswa wanita lebih perhatian di kelas, lebih termotivasi belajar, belajar lebih tekun, serta lebih berpartisipasi dalam kegiatan sekolah (Seifert dan Sutton, 2009; Santrock, 2010). 
Menurut Teori Perkembangan Kognitif Piaget (Santrock, 2010) bahwa, secara normal karakteristik sampel (siswa SMA/Sederajad) telah mencapai kemampuan berpikir abstrak saat mencapai usia 11 tahun. Aspek kemampuan daya abstrak populasi yang lemah menunjukkan perkembangan intelegensi mereka terlambat. Banyak hal yang menyebabkan fenomena tersebut di atas. Karakter sampel yang didominasi $56 \%$ berasal dari wilayah sekolah pinggiran (SMAN 1 Bluto berjarak $\pm 15 K M$ dan MA Al-Amin 1 Putri berjarak $\pm 35 K M$ dari Pusat Kota Sumenep), serta karakter populasi yang memegang budaya (etnis) tradisional yang kuat diduga menyebabkan fenomena rendahnya kemampuan berpikir abstrak yang digolongkan berpikir tingkat tinggi. Vygotsky mengatakan perkembangan kognitif tidak terlepas dari kegiatan kultural dan sosialnya (Holland, dkk, 2001 Santrock, 2010). Sebagai masyarakat tradisional dan umumnya berasal dari tingkat ekonomi bawah-menengah, mereka cenderung mendapat pola asuhan authoritarian, dimana orang tua siswa mewajibkan anaknya untuk mengikuti petunjuk (patuh) dan mengormati mereka (Santrock, 2010), serta orang tua kurang menekankan standar yang tinggi untuk anaknya (Santrock, 2010). Hal ini berakibat siswa berkemampuan komunikasi rendah, cemas menghadapi situasi sosial, dan kurang inisiatif. Dalam Teori Ekologi Bronfenbrenner (2000), bahwa peran serta aktif mempengaruhi pengamalam siswa dan guru. Kultur siswa (masyarakat) yang tradisional (islami) yang memegang adat istiadat dan nilai yang kuat, menempatkan dominasi pria daripada wanita dalam pendidikan (Santrock, 2010). Sehingga, siswa wanita yang mendominasi secara kuantitas cenderung pasif dalam kegiatan pembelajaran dan intelegensi kognitif abstrak mereka rendah. Selain itu, status ekonomi yang menengah ke bawah mempengaruhi dan merusak kemampuan mereka dalam belajar (Seifert dan Sutton, 2009; Santrock, 2010) karena keterbatasan mereka untuk memperoleh akses pendidikan yang bermutu.

Kecenderungan metode pembelajaran guru di sekolah (konvensional) yang cenderung menghafal materi, serta metode pembelajaran bergaya otoriter (otoritarian) yang menekankan menjaga ketertiban kelas berdampak berkurangnya memberikan ruang kepada siswa untuk menggunakan gaya belajar siswanya. Guru yang otoriter akan mengekang dan mengontrol siswa, serta tidak banyak melakukan percakapan, pasif, tidak membuat inisiatif, serta keterampilan komunikasi yang buruk (Santrock, 2010). Kemampuan abstraksi adalah pemikiran didasarkan pada gagasan umum tentang konsep dari berbagai hal dan peristiwa (Hudgins, 1982). Bisa jadi, sebuah konsep individu yang sulit dipahami orang lain, sebab mereka tidak memiliki kesepahaman sama (Hudgins, 1982). Untuk membangun kemampuan abstrak siswa yang baik, siswa diberi kesempatan mengemukakan pendapatnya, menjadi pemikir independen dan mandiri.

Dari hasil analisis model persamaan struktural di atas juga dapat dilihat, hubungan kausal antara variabel laten kecerdasan emosional terhadap prestasi belajar tidak signifikan. Artinya kecerdasan emosional tidak berpengaruh terhadap prestasi belajar. Hubungan kausal antara variabel laten kecerdasan intelektual terhadap prestasi belajar signifikan dengan nilai koefisien jalur untuk variabel kecerdasan intelektual 0,387. Artinya kecerdasan intelektual berpengaruh terhadap prestasi belajar, dimana semakin rendah kecerdasan intelektual maka prestasi belajar akan turun sebesar 0,387.

Bahwa, kecerdasan emosional memiliki domain berbeda dengan kecerdasan intelektual sehingga kecerdasan emosional tidak dapat dimasukkan ke dalam konsep intelegensi (Gardner 1998 dalam Santrock, 2010). Tes IQ pada dasarnya dirancang untuk mengidentifikasi kemampuan anak belajar (Hudgins, 1982) di sekolah, yang lebih memfokuskan pada aspek kognitif-intelektual. Semakin tinggi IQ individu maka semakin mudah mereka menyerap pelajaran (Santrock, 2010) yang menjadikan prestasi belajar mereka lebih baik. Meski demikian, peningkatan skor IQ tidak dapat menjadi dasar terhadap prestasi belajar siswa, sebab aspek motivasi belajar dan pengalaman pendidikan sebelumnya (Santrock, 2010) yang lebih menentukan.

Hasil dari evaluasi Goodness of fit, nilai RMSEA didapatkan 0,061, dimana nilai ini kurang dari 0,08 . Hal ini menunjukkan bahwa model yang dikembangkan berdasarkan teori pada penelitian ini masih dapat dikatakan sesuai dengan kondisi SMA/MA di Sumenep. Akan tetapi pengembangan model struktural pada penelitian ini hanya berlaku untuk studi kasus pengaruh kecerdasan emosional dan kecerdasan intelektual terhadap prestasi belajar SMA/MA di Kabupaten Sumenep daratan (tidak termasuk daerah kepulauan), sehingga tidak bisa digeneralisasi untuk kasus yang lainnya. 


\section{Simpulan}

Kesimpulan dari penelitian ini adalah sebagai barikut :

1. Indikator yang bisa digunakan untuk menjelaskan kecerdasan emosional adalah dorongan berprestasi, kemauan mendengarkan masalah orang lain dan kemampuan bekerja sama. Sedangkan indikator yang bisa mengukur kecerdasan intelektual adalah pemahaman, daya ingat, kemampuan verbal, kemampuan numerik, daya abstrak dan penalaran umum.

2. Kecerdasan emosional tidak berpengaruh secara nyata terhadap prestasi belajar.Sedangkan kecerdasan intelektual berpengaruh dengan nilai koeffisient path sebesar 0,387, dimana semakin rendah kecerdasan intelektual maka prestasi belajar akan turun sebesar 0,387.

\section{DAFTAR PUSTAKA}

Anastasi, A dan Urbian. (1997). Tes Psikologi. Jakarta : PT Prihanllindo.

Eysenck, HJ. (1981). Intelligence : The Batle for The Mind. Sydney : Pan Book.

Bronfenbrenner, U. (2000). Ecological Theory. Washington DC \& New York: American Psychological Assosiation and Oxford University Press

Ferdinand, A. (2000). Struktural Equation Modelling : Teori Konsep SEM. Semarang :Badan Penerbit Universitas Diponegoro.

Ghozali I dan Fuad. (2005). Struktural Equation Modeling: Teori, Konsep dan Aplikasi Lisrel. Semarang : Penerbit Universitas Diponogoro.

Goleman, Daniel. (2000). Emitional Intelligence (terjemahan). Jakata : PT Gramedia Pustaka Utama.

Goleman, Daniel. (2002). Working With Emotional Intelligence (terjemahan). Jakarta : PT. Gramedia Pustaka Utama.

Gregory, R.J. (2000). Psychology Testing (3th ed). Boston: Allyn and Bacon

Hudgins, Bryce B., et all. (1982). Educational Psychology. Itasca, Illionis: F.E. Peacock Publisher, Inc. Joseph, G. (1978). Interpreting Phychological Test Data. Vol.1, New York VNR.

Kline, Rex B. (2005). Principle and Practice of Structural Equation Modelling. Second Edition. New York : The Guilford Press.

Santrock, John W. (2010). Psikologi Pendidikan. Jakarta: Kencana

Saphiro, Lawrenvce. (1998). Mengajarkan Emotional Intellengence Pada Anak. Jakarta : Gramedia.

Seifert dan Sutton. (2009). Educational Psychology 2nd Ed. Zurich Switzerland: Globaltext

Sharma, S. (1996). Applied Multivarite Techniques. John Wiley \& Sons. Inc.

Slameto. (1995). Belajar dan faktorfaktor yang mempengaruhinya. Jakarta: PT Rineka Cipta.

Sternberg, RJ. (2000). Looking Back and Looking Forward Inteligence. Philadelphia: Psychology Press.

Trihandini, Fabiola M. (2005). Analisis Pengaruh Kecerdasan Intelektual, Kecerdasan Emosional dan Kecerdasan Spriritual Terhadap Kinerja Karyawan. Tesis. Semarang : Program Studi Magister Manajemen Pascasarjana Universitas Diponegoro.

Wahyuningsih, Amalia S. (2004). Hubunan Antara Keceerdasan Emosional dengan Prestasi Belajar pada Siswa Kelas II SMU LAB School Jakarta Timur. Skripsi. Jakarta : Fakultas Psikologi Universitas Persada Indonesia Y.A.I.

Winarno, A (2001). Kecerdasan Emosional. Jakarta : LAN

Winkel, WS (1997). Psikologi Pendidikan dan Evaluasi Belajar. Jakarta : Gramedia 